\title{
The Surprising Power of Neighborly Advice
}

\section{Citation}

Gilbert, Daniel T., Matthew A. Killingsworth, Rebecca. N. Eyre, and Timothy D. Wilson. 2009. The surprising power of neighborly advice. Science 323, no. 5921: 1617-1619.

\section{Published Version}

http://dx.doi.org/10.1126/science.1166632

\section{Permanent link}

http://nrs.harvard.edu/urn-3:HUL.InstRepos:3110937

\section{Terms of Use}

This article was downloaded from Harvard University's DASH repository, and is made available under the terms and conditions applicable to Other Posted Material, as set forth at http:// nrs.harvard.edu/urn-3:HUL.InstRepos:dash.current.terms-of-use\#LAA

\section{Share Your Story}

The Harvard community has made this article openly available.

Please share how this access benefits you. Submit a story.

Accessibility 


\section{Science \\ AIAAAS}

The Surprising Power of Neighborly Advice

Daniel T. Gilbert, et al.

Science 323, 1617 (2009);

DOI: $10.1126 /$ science. 1166632

\section{The following resources related to this article are available online at www.sciencemag.org (this information is current as of June 3, 2009 ):}

Updated information and services, including high-resolution figures, can be found in the online version of this article at:

http://www.sciencemag.org/cgi/content/full/323/5921/1617

Supporting Online Material can be found at: http://www.sciencemag.org/cgi/content/full/323/5921/1617/DC1

A list of selected additional articles on the Science Web sites related to this article can be found at:

http://www.sciencemag.org/cgi/content/full/323/5921/1617\#related-content

This article cites 39 articles, 10 of which can be accessed for free:

http://www.sciencemag.org/cgi/content/full/323/5921/1617\#otherarticles

This article appears in the following subject collections:

Psychology

http://www.sciencemag.org/cgi/collection/psychology

Information about obtaining reprints of this article or about obtaining permission to reproduce this article in whole or in part can be found at:

http://www.sciencemag.org/about/permissions.dtl 
resembles the role of ankyrin-G in axon initial segments, where it binds to and coordinates the localization of three proteins required for the initiation and regulation of action potentials (Nav1.6, KCNQ2 and 3 channels, and 186-kD neurofascin) $(29,30)$. Without ankyrin-G, axon initial segments lose these proteins and express dendritic markers (31). In epithelial cells, ankyrin-G is required both for targeting E-cadherin to the plasma membrane and for biogenesis of the lateral membrane $(6,17)$. We hypothesize that, in addition to targeting the CNG channel, ankyrin-G can interact with other ROS membrane proteins, as well as proteins required for their ROS trafficking, and these interactions are essential for ROS morphogenesis. A conserved ankyrin-G-based mechanism may thus be shared by photoreceptors, neurons, and epithelial cells that accomplishes both the targeting of membrane-spanning proteins to specialized plasma membrane domains as well as assembly and/or maintenance of these domains.

\section{References and Notes}

1. K. Matulef, W. N. Zagotta, Annu. Rev. Cell Dev. Biol. 19, 23 (2003)
2. S. Huttl et al., J. Neurosci. 25, 130 (2005).

3. P. M. Jenkins et al., Curr. Biol. 16, 1211 (2006).

4. S. Michalakis et al., J. Biol. Chem. 281, 35156 (2006)

5. G. Ayalon, ]. Q. Davis, P. B. Scotland, V. Bennett, Cell 135, 1189 (2008).

6. K. Kizhatil et al., J. Biol. Chem. 282, 26552 (2007).

7. J. S. Lowe et al., J. Cell Biol. 180, 173 (2008).

8. P. J. Mohler et al., Proc. Natl. Acad. Sci. U.S.A. 101, 17533 (2004).

9. D. Zhou et al., J. Cell Biol. 143, 1295 (1998).

10. P. Wohlfart, W. Haase, R. S. Molday, N. J. Cook, J. Biol. Chem. 267, 644 (1992).

11. Materials and methods are available as supporting material on Science Online.

12. K. Kizhatil, N. K. Sandhu, N. S. Peachey, V. Bennett, Exp. Eye Res. 88, 57 (2009).

13. B. Wiesner et al., J. Cell Biol. 142, 473 (1998).

14. X. Zhang, J. Q. Davis, S. Carpenter, V. Bennett, J. Biol. Chem. 273, 30785 (1998).

15. T. Y. Chen et al., Nature 362, 764 (1993).

16. T. Matsuda, C. L. Cepko, Proc. Natl. Acad. Sci. U.S.A. 101, 16 (2004).

17. K. Kizhatil, V. Bennett, J. Biol. Chem. 279, 16706 (2004).

18. H. Kondo et al., Invest. Ophthalmol. Vis. Sci. 45, 4433 (2004)

19. Single-letter abbreviations for the amino acid residues are as follows: A, Ala; C, Cys; D, Asp; E, Glu; F, Phe; G, Gly; H, His; I, Ile; K, Lys; L, Leu; M, Met; N, Asn; P, Pro; Q, Gln; R, Arg; S, Ser; T, Thr; V, Val; W, Trp; and Y, Tyr.

20. S. A. Baker et al., J. Cell Biol. 183, 485 (2008)
21. A. Poetsch, L. L. Molday, R. S. Molday, J. Biol. Chem. 276, 48009 (2001).

22. J. Nguyen-Legros, D. Hicks, Int. Rev. Cytol. 196, 245 (2000).

23. C. Insinna, N. Pathak, B. Perkins, I. Drummond, J. C. Besharse, Dev. Biol. 316, 160 (2008).

24. V. Bennett, ]. Healy, Trends Mol. Med. 14, 28 (2008).

25. K. Kizhatil et al., J. Biol. Chem. 282, 2029 (2007).

26. P. J. Mohler, W. Yoon, V. Bennett, J. Biol. Chem. 279, 40185 (2004).

27. V. Muresan et al., Mol. Cell 7, 173 (2001).

28. S. A. Madreperla, M. Edidin, R. Adler, J. Cell Biol. 109, 1483 (1989).

29. S. M. Jenkins, V. Bennett, J. Cell Biol. 155, 739 (2001).

30. Z. Pan et al., J. Neurosci. 26, 2599 (2006).

31. K. L. Hedstrom, Y. Ogawa, M. N. Rasband, J. Cell Biol. 183, 635 (2008).

32. We thank ]. Hoffman for constructing the plasmids used in the study. V.Y.A. was funded by NIH grant EY12859. V.B. is an investigator of Howard Hughes Medical Institute (HHMI) and was funded by HHMI.

Supporting Online Material

www.sciencemag.org/cgi/content/full/323/5921/1614/DC1 Materials and Methods

Figs. $\mathrm{S} 1$ to $\mathrm{S} 6$

References

15 December 2008; accepted 2 February 2009

10.1126/science.1169789

\section{The Surprising Power of Neighborly Advice}

\section{Daniel T. Gilbert, ${ }^{1 *}$ Matthew A. Killingsworth, ${ }^{1}$ Rebecca N. Eyre, ${ }^{1}$ Timothy D. Wilson ${ }^{2}$}

Two experiments revealed that (i) people can more accurately predict their affective reactions to a future event when they know how a neighbor in their social network reacted to the event than when they know about the event itself and (ii) people do not believe this. Undergraduates made more accurate predictions about their affective reactions to a 5-minute speed date $(n=25)$ and to a peer evaluation $(n=88$ ) when they knew only how another undergraduate had reacted to these events than when they had information about the events themselves. Both participants and independent judges mistakenly believed that predictions based on information about the event would be more accurate than predictions based on information about how another person had reacted to it.

$\mathrm{P}$ eople make systematic errors when attempting to predict their affective reactions to future events, and these errors have socia $(1-3)$, economic $(4-8)$, legal $(9,10)$, and medical (11-22) consequences. For example, people have been shown to overestimate how unhappy they will be after receiving bad test results (23), becoming disabled $(14,19-21)$, or being denied a promotion (24), and to overestimate how happy they will be after winning a prize (6), initiating a romantic relationship (24), or taking revenge against those who have harmed them (3). Research suggests that the main reason people mispredict their affective reactions to future events is

${ }^{1}$ Department of Psychology, Harvard University, Cambridge, MA 02138, USA. '2Department of Psychology, University of Virginia, Charlottesville, VA 22904, USA.

*To whom correspondence should be addressed. E-mail: gilbert@wjh.harvard.edu that they imagine those events inaccurately (25). For example, people tend to imagine the essential features of future events but not the incidental features (26-28), the early moments of future events but not the later moments $(17,24)$, and so on. When mental simulations of events are inaccurate, the affective forecasts that are based on them tend to be inaccurate as well.

Attempts to improve the accuracy of affective forecasting have generally concentrated on improving the accuracy of mental simulation, and the results have been disappointing (29-33). Some interventions have failed (16), and those that have successfully reduced forecasting errors in one situation have typically failed to reduce them in others $(27,29)$. But mental simulation is not the only way to make an affective forecast. The 17th century writer François de La Rochefoucauld suggested that rather than mentally simulating a future event, people should consult those who have experienced it. "Before we set our hearts too much upon anything," he wrote, "let us first examine how happy those are who already possess it" (34). La Rochefoucauld was essentially suggesting that forecasters should use other people as surrogates for themselves, and the advantages of his "surrogation strategy" are clear: Because surrogation does not rely on mental simulation, it is immune to the many errors that inaccurate simulations produce.

The disadvantages of surrogation are also clear: Individuals differ, and thus, one person's affective reaction is almost certainly an imperfect predictor of another's. But there are at least two reasons to suspect that affective reactions are not as different as people may believe. First, affective reactions are produced in large part by physiological mechanisms that are evolutionarily ancient, which is why people the world over have very different beliefs and opinions but very similar affective reactions to a wide range of stimuli (35), preferring warm to cold, satiety to hunger, friends to enemies, winning to losing, and so on. An alien who knew all the likes and dislikes of a single human being would know a great deal about the entire species. Second, people tend to marry, befriend, work with, and live near those who share their preferences and personality traits $(36,37)$, and thus the people from whom they are especially likely to receive surrogation information - the neighbors in their social networks - are especially likely to share their affective reactions. In short, there is little disagreement among people about the sources of pleasure and pain, and even less disagreement among neighbors. These facts suggest that surrogation may be more powerful than people realize. 
We tested this hypothesis in two experiments The events we studied were (i) speed dating, in which undergraduate women predicted how much they would enjoy a 5-min speed date with an undergraduate man, and (ii) peer-evaluation, in which undergraduates predicted how they would feel after being evaluated by a peer (38). In both experiments, we gave participants either information that allowed them to simulate the future event (simulation information) or information about the affective reaction of a fellow undergraduate who had experienced the same event in the past (surrogation information). We predicted that participants would make more accurate affective forecasts when they knew nothing about the future event and knew only how someone in their social network had reacted to it.

In experiment 1 , we created a speed-dating service in which undergraduate men and women had brief "getting acquainted" conversations. We included 8 men and 33 women who were undergraduates at Harvard University, unmarried, and self-identified as heterosexual. There were eight speed-dating sessions, each of which included one of the eight men and between two and eight of the women. No one participated in more than one session. In each session, the man was first escorted to the speed-dating room, where he completed a short personal profile listing his name, age, height, hometown, and residence, as well as his favorite movie, sport, book, song, food, hangout, and college class. His photograph was taken and printed. Next, a woman was escorted to the speed-dating room and left to have a 5-min private conversation with the man. Next, the experimenter escorted the woman to another room where she reported how much she had enjoyed the speed date by marking a $100-\mathrm{mm}$ continuous "enjoyment scale" whose end points were marked not at all and very much. This report is hereinafter referred to as her affective report.

Next, a second woman was given one of two kinds of information: simulation information (which consisted of the man's personal profile and photograph) or surrogation information (which consisted of the affective report provided by the first woman). The second woman was then asked to predict (on the enjoyment scale) how much she would enjoy her speed date with the man. This prediction is hereinafter referred to as her affective forecast.

After making her prediction, the second woman was shown the kind of information (simulation or surrogation) that she had not already received. We did this to ensure that each woman had the same information about the man before the actual speed date. The only difference between the two conditions, then, was whether the second woman had surrogation information or simulation information when she made her forecast.

Next, the second woman was escorted to the dating room, had a speed date, and then reported how much she enjoyed it (on the enjoyment scale). This report is hereinafter referred to as her affective report. The second woman also reported whether she believed that simulation information or surrogation information would have allowed her to make the more accurate prediction about the speed date she had and about a speed date that she might have in the future. This process was repeated in an alternating pattern for each additional woman until the session ended. [For a full description of the procedure, see (39)].

Affective forecasting error was calculated by taking the absolute difference between the affective forecast and affective report of each woman (except the first woman, who made no affective forecast). Raw data may be seen in fig. S1, a and $\mathrm{b}$. Women were considerably more accurate when they used surrogation information (mean \pm $\mathrm{SD}, 11.42 \pm 8.70 \mathrm{~mm}$ ) than when they used simulation information $(22.38 \pm 10.79 \mathrm{~mm})[t(23)=$ $2.78, P=0.01]$. Relative to simulation, surrogation reduced the size of the affective forecasting error by $49 \%$. Ironically, $75 \%$ of the women believed that simulation information would have allowed them to make a more accurate forecast about their date with the man they met, and 84\% believed that simulation information would allow them to make a more accurate forecast about a future date with a different man.

One potential concern about these results is that the simulation information (which was provided by the men) may not have been entirely accurate, and its inaccuracy may have contributed to the inaccuracy of the forecasts that were based on it. The data do not support this suggestion. If men portrayed themselves as better than they actually were, then women who used simulation information should have overestimated how much they would enjoy the date. In fact, women underestimated how much they would enjoy the date (see supporting online text). Nonetheless, we conducted a second experiment in which simulation information was completely accurate. In addition, we collected data on the perceived utility of simulation and surrogation from an independent panel of judges rather than from the participants themselves.

Experiment 2 had three parts. In part one, 17 women and 8 men who were undergraduates at Harvard University served as surrogates. Surrogates were told that they would write a story and that a peer in an adjoining room would evaluate the story and use it to classify them as one of three personality types. In fact, there was no peer. Surrogates read detailed descriptions of the type A, type B, and type $\mathrm{C}$ personalities. The description of the type A personality was positive, the description of the type $\mathrm{B}$ personality was neutral, and the description of the type $\mathrm{C}$ personality was negative. For example, people with type $\mathrm{C}$ personalities were said to "sacrifice their beliefs because they seek contentment rather than challenge" and "when long-term relationships end it is usually because the person's partner has found a more suitable alternative." Previous studies have shown that few people classify themselves as type $\mathrm{C}$, and most feel unhappy when they are so classified by a peer $(24,40)$. Surrogates then wrote stories that were ostensibly given to their peer in the adjoining room. Ten minutes later, the experimenter informed the surrogates that they had been classified as type $\mathrm{C}$ by their peer. Ten minutes later, surrogates reported their current affective state by marking a continuous 100-mm "feeling scale" whose end points were labeled very bad and very good. These reports are hereinafter referred to as the surrogates' affective reports.

In part two, 28 men and 60 women who were undergraduates at Harvard University served as forecasters. Forecasters were also told that they would write a story and that a peer would evaluate the story and then classify them as one of three personality types. Half the forecasters were randomly assigned to receive simulation information. These forecasters were shown complete descriptions of the three personality types and were asked to predict (on the feeling scale) how they would feel if their peer classified them as each of the three types. These forecasters, therefore, had complete and accurate information about the upcoming event.

The remaining forecasters were assigned to receive surrogation information. Instead of being shown the descriptions of the three personality types, these forecasters were shown the affective report of one randomly selected surrogate from part one who had been classified as a type $\mathrm{C}$, and they were asked to predict how they would feel if their peer classified them as each of the three types. These predictions are hereinafter referred to as the forecasters' affective forecasts. After making these forecasts, forecasters in the surrogation condition were shown the descriptions of the three personality types.

All forecasters then wrote a story, were told that their peer had classified them as a type $\mathrm{C}$, and reported how they felt (on the feeling scale). These reports are hereinafter referred to as the forecasters' affective reports.

Affective forecasting error was calculated by taking the absolute value of the difference between each forecaster's affective forecast and affective report. (Raw data may be seen in fig. S2, a and b). As in experiment 1 , forecasters were considerably more accurate when they used surrogation information $(12.50 \pm 14.10 \mathrm{~mm})$ than when they used simulation information (33.75 \pm $22.01 \mathrm{~mm})[t(86)=5.38, P<0.001]$. Relative to simulation, surrogation reduced the size of the affective forecasting error by $63 \%$.

In part three, 23 men and 40 women who were undergraduates at Harvard University served as judges. The judges were told about the procedure for part one and were asked to rank several pieces of information based on how useful each piece would be in allowing them to estimate the affective response of a participant. These included simulation information (complete descriptions of each of the three personality types) and surrogation information (the affective report of another randomly selected participant). Judges 
believed that simulation information would be more useful (rank, mean $\pm \mathrm{SD}, 1.45 \pm 0.694$ ) than surrogation information $(2.1 \pm 0.718)[t(61)=$ 4.18, $P<0.001]$.

In two experiments, participants more accurately predicted their affective reactions to a future event when they knew how a neighbor in their social network had reacted to it than when they knew about the event itself. Women made more accurate predictions about how much they would enjoy a date with a man when they knew how much another woman in their social network enjoyed dating the man than when they read the man's personal profile and saw his photograph. Men and women made more accurate predictions about how they would feel after being evaluated by a peer when they knew how another person in their social network had felt after being evaluated than when they previewed the evaluation itself. Although surrogation trumped simulation, both participants and independent judges had precisely the opposite intuition (41). By a wide margin, they believed that simulation was more likely than surrogation to produce accurate affective forecasts.

Two points are worthy of note. First, surrogation is by definition superior to simulation when individual differences are relatively small and simulations errors are relatively large, and it is inferior to simulation when the opposite is true. Although there is no way to know which of these is more typical in everyday life, the situations we studied - dating and peer-evaluation - are by no means exotic. Furthermore, our experiments provided an especially conservative test of the power of surrogation because participants received surrogation information from a person who happened to attend the same university as they did but with whom they had no personal relationship. In everyday life, people are likely to receive surrogation information from those with whom they affiliate, and because people affiliate with those who are similar, their surrogates are even more likely to share their preferences and predilections. This suggests that the potential utility of surrogation information may be greater in vivo than our experiments suggest.
Second, although our experiments demonstrate the power of surrogation, they also suggest that people may not normally take advantage of this power. Our participants mistakenly believed that simulation was the superior strategy even after it had failed them, which suggests that people may be reluctant to engage in surrogation if they have the opportunity to do otherwise. Participants in the surrogation conditions of our experiments were unable to engage in mental simulation because they knew little or nothing about the future event and thus had no choice but to rely on the surrogation information we provided. But given people's mistaken beliefs about the relative ineffectiveness of surrogation and their misplaced confidence in the accuracy of their own mental simulations (39), it seems likely that in everyday life, La Rochefoucauld's advice-like the advice of good neighbors - is more often than not ignored. When we want to know our emotional futures, it is difficult to believe that a neighbor's experience can provide greater insight than our own best guess.

\section{References and Notes}

1. K. Kawakami, E. Dunn, F. Karmali, ]. F. Dovidio, Science 323, 276 (2009).

2. T. D. Wilson, D. B. Centerbar, D. A. Kermer, D. T. Gilbert, J. Pers. Soc. Psychol. 88, 5 (2005)

3. K. M. Carlsmith, T. D. Wilson, D. T. Gilbert, J. Pers. Soc. Psychol. 95, 1316 (2008).

4. D. T. Gilbert, J. E. J. Ebert, J. Pers. Soc. Psychol. 82, 503 (2002).

5. S. L. Wood, ]. R. Bettman, J. Consum. Psychol. 17, 188 (2007).

6. D. A. Kermer, E. Driver-Linn, T. D. Wilson, D. T. Gilbert, Psychol. Sci. 17, 649 (2006).

7. N. Sevdalis, N. Harvey, Psychol. Sci. 18, 678 (2007)

8. K. S. Kassam, D. T. Gilbert, A. Boston, T. D. Wilson J. Exp. Soc. Psychol. 44, 1533 (2008).

9. J. A. Blumenthal, Indiana Law J. 80, 155 (2005).

10. J. Bronsteen, C. Buccafusco, J. Masur, Columbia Law Rev. 108, 1516 (2008).

11. R. Rhodes, J. J. Strain, Camb. Q. Healthc. Ethics 17, 54 (2008).

12. D. I. Shalowitz, E. Garrett-Mayer, D. Wendler, PLoS Med. 4, e35 (2007).

13. J. Baron et al., Med. Decis. Making 23, 422 (2003).

14. P. A. Ubel, G. Loewenstein, N. Schwarz, D. Smith, Health Psychol. 24, 557 (2005).

15. P. A. Ubel, G. Loewenstein, C. Jepson, Qual. Life Res. 12, 599 (2003).
16. P. A. Ubel et al., Med. Decis. Making 21, 190 (2001).

17. J. Riis et al., J. Exp. Psychol. Gen. 134, 3 (2005).

18. P. Menzel, P. Dolan, ]. Richardson, J. A. Olsen, Soc. Sci. Med. 55, 2149 (2002).

19. G. L. Albrecht, P. J. Devlieger, Soc. Sci. Med. 48, 977 (1999).

20. N. F. Boyd, H. J. Sutherland, K. Z. Heasman, D. L. Tritchler, B. J. Cummings, Med. Decis. Making 10, 58 (1990).

21. D. L. Sackett, G. W. Torrance, J. Chronic Dis. 31, 697 (1978).

22. P. H. Ditto, N. A. Hawkins, Health Psychol. 24, 563 (2005).

23. T. D. Wilson, T. Wheatley, ]. Kurtz, E. W. Dunn, D. T. Gilbert, Pers. Soc. Psychol. Bull. 30, 340 (2004)

24. D. T. Gilbert, E. C. Pinel, T. D. Wilson, S. J. Blumberg, T. P. Wheatley, J. Pers. Soc. Psychol. 75, 617 (1998).

25. D. T. Gilbert, T. D. Wilson, Science 317, 1351 (2007).

26. N. Liberman, Y. Trope, Science 322, 1201 (2008).

27. T. D. Wilson, T. P. Wheatley, J. Meyers, D. T. Gilbert, D. Axsom, J. Pers. Soc. Psychol. 78, 821 (2000).

28. E. W. Dunn, T. D. Wilson, D. T. Gilbert, Pers. Soc. Psychol. Bull. 29, 1421 (2003).

29. P. A. Ubel, G. Loewenstein, C. Jepson, J. Exp. Psychol. Appl. 11, 111 (2005).

30. L. J. Damschroder, B. J. Zikmund-Fisher, P. A. Ubel, Soc. Sci. Med. 61, 267 (2005).

31. T. D. Wilson, ]. Meyers, D. T. Gilbert, Pers. Soc. Psychol. Bull. 27, 1648 (2001).

32. P. Ayton, A. Pott, N. Elwakili, Think. Reason. 13, 62 (2007).

33. E. W. Dunn, M. A. Brackett, C. Ashton-James, E. Schneiderman, P. Salovey, Pers. Soc. Psychol. Bull. 33, 85 (2007).

34. F. de La Rochefoucauld, Collected Maxims and Other Reflections (Oxford Univ. Press, Oxford, 2007), p. 354

35. D. A. van Hemert, Y. H. Poortinga, F. J. R. van de Vijver, Cogn. Emotion 21, 913 (2007).

36. M. McPherson, L. Smith-Lovin, K. Cook, Annu. Rev. Sociol. 27, 415 (2001)

37. K. Lee et al., J. Pers. Soc. Psychol. 96, 460 (2009).

38. Materials and methods are available as supporting material on Science Online.

39. D. W. Griffin, D. Dunning, L. Ross, J. Pers. Soc. Psychol. 59, 1128 (1990)

40. D. T. Gilbert, M. D. Lieberman, C. K. Morewedge, T. D. Wilson, Psychol. Sci. 15, 14 (2004).

41. N. Epley, D. Dunning, J. Pers. Soc. Psychol. 79, 861 (2000).

42. We acknowledge the support of research grant BCS-0722132 from NSF to D.T.G. and T.D.W.

\section{Supporting Online Material}

www.sciencemag.org/cgi/content/full/323/5921/1617/DC1

Materials and Methods

SOM Text

Figs. S1 and S2

30 September 2008; accepted 5 February 2009 10.1126/science.1166632 